Acta vet. scand. $1969,10,146-167$.

From the Department of Obstetrics and Gynaecology,

Royal Veterinary College, Stockholm, and

Veterinary Medical Laboratory, örebro, Sweden.

\title{
THE RELATIONSHIP \\ BETWEEN THE CALIFORNIA MASTITIS TEST, WHITESIDE TEST, BRABANT MASTITIS REACTION, CATALASE TEST, AND DIRECT CELL COUNTING OF MILK
}

By

S. Astermark, H. Funke and I. Engan-Skei

Comparisons between different indirect test reactions and the cell levels obtained by direct cell counting are reported in a large number of papers. As is evident from the literature cited below, results and opinions of the tests' reliability vary.

The aim of these investigations was to study the correlation for different types of milk samples between the indirect methods of testing, California Mastitis Test, Whiteside Test, Brabant Mastitis Reaction, Catalase Test, and the cell content as determined by direct cell counting according to Prescott \& Breed (1910).

The correlation has been studied partly between each enumerated indirect test and the direct cell counting, and partly by certain comparisons between the different indirect tests. How the correlation behaves in material from different regions and with different mean cell contents has been studied with the California Mastitis Test. Possible variations in mean cell counts for individual farms' California Mastitis Test reactions were investigated in the case of + and ++ reactions. Moreover, the correlation between the California Mastitis Test and direct cell counts is compared for different types of samples (udder quarter, churn and weighing vessel samples). 
The following system is used to indicate the degree of significance: ${ }^{*} \mathrm{P}<0.05 ;{ }^{*} \mathrm{P}<0.01 ;{ }^{\star \star}{ }^{\star} \mathrm{P}<0.001$. The abbreviations used are as follows:

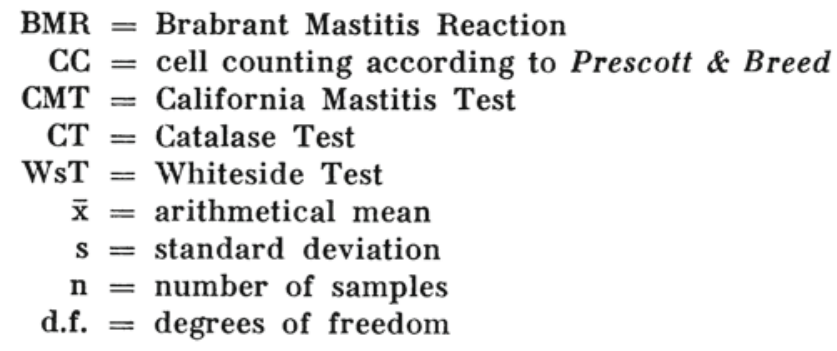

\section{LITERATURE}

Whiteside Test. This test was described by Whiteside (1939).

The underlying mechanism of WsT is not completely clear. Dunn et al. (1943) reported that leucocytes are directly or indirectly responsible for the reaction. Jensen (1957) considered that calcium ions also play a rôle in the reaction. Petersen et al. (1950) stated that the reaction was caused by adsorption of fibrin onto the white cells in the milk. Schalm \& Noorlander (1957) found that fat content of the milk can also have an effect, while Kästli (1963) stated that the clot formation arises from a reaction between sodium and calcium ions and the cell albumen.

The relationship between the cell content of milk and WsT results has been the subject of many investigations. Opinion on Ws'T's suitability for estimation of milk cell content varies, partly because different investigations had different objectives.

Murphy \& Hanson (1941) divided the reactions into six classes and stated that results with $2+$ or higher correlated well with a cell content of over $5 \times 10^{5}$ per $\mathrm{ml}$. However the majority of investigations reveal that in general the range of variation for the different cases is large, both for foremilk and bulk milk, and that no well-defined cell level limits could be seen in different cases (Petersen 1952, Obiger 1957, Andersen 1957, Easterday et al. 1958, Strozzi \& Negretti 1959, Dedié \& Kielwein 1960, Barnum \& Newbould 1961, Ewbank 1962, and Postle \& Blobel 1965).

California Mastitis Test. This test was elaborated by Schalm \& Noorlander.

The nature of the positive CMT reaction was not explained by Schalm \& Noorlander, but it has been the subject of several investigations and theories. Obiger (1961) stated that the CMT 
reaction can be considered as a combination between the test reagent and certain milk proteins. The reaction entails a certain electrochemical potential in the proteins. Dedié \& Kielwein maintained that probably other proteins besides cell proteins react with the test solution. Carroll \& Schalm (1962) in experiments with DNA-ase showed that a positive CMT reaction would disappear with the addition of a sufficient quantity of the enzyme. Jaartsveld (1961) also reported that DNA in the cell nuclei was responsible for the viscosity which occurs when milk of heavy leucocyte content is mixed with the test solution.

The degree to which CMT results correspond with the cell content has been studied extensively. Leidl \& Schalm (1961) reported that a CMT reaction of $1+$ generally corresponds with a cell level of more than $5 \times 10^{5}$ cells per $\mathrm{ml}$ in samples from churns. However, the authors reported that the cell values varied considerably within reactions and demonstrated large standard deviations for them. Baier (1964) also reported large standard deviations, and his work showed that $38.3 \%$ of samples with CMT \pm reactions contained more than $5 \times 10^{5}$ cells per ml, while with a reaction of $1+10.6 \%$ of samples had less than $5 \times 10^{5}$ cells per $\mathrm{ml}$.

That cell levels for given CMT reactions have a wide range of variation with considerable overlapping was further demonstrated by McKenzie \& Cameron-Mackintosh (1958); Gram \& Marker (1959); Dedié \& Kielwein; Barnum \& Newbould; Leidl et al. (1961); Ewbank; Klein \& Thomas (1962); Postle \& Blobel; Daniel et al. (1966); Smith \& Schultze (1966); Schultze \& Smith (1966) and Miller \& Kearns (1967).

Brabant Mastitis Reaction. BMR is a modification of CMT and was elaborated by Jaartsveld (1962). The test is performed by measuring with a capillary tube the increase in viscosity which arises when infected milk is mixed with the reagent. No attention is paid to clot formation in this test.

The relation of BMR reactions and cell levels obtained from direct cell counts was studied by Jaartsveld (1962). His investigations showed, however, that large, and to a great extent, similar ranges of variation occur for cell levels lying within the two lowest reactions (negative and one dot). For both these reactions cell values from 0 to more than $5 \times 10^{5}$ occurred. The negative reaction was obtained nevertheless from a greater percentage of samples with low cell values than the one dot reaction. Large 
T a b l e 1. Summary of material used. Tests carried out on the day of sampling.

\begin{tabular}{|c|c|c|}
\hline Type of sample & Number & $\begin{array}{l}\text { Correlation and } \\
\text { relationship studied }\end{array}$ \\
\hline Udder quarter & 1532 & $\begin{array}{l}\mathrm{CC}-\mathrm{CMT} \\
\mathrm{CC}-\mathrm{CT}\end{array}$ \\
\hline \multicolumn{3}{|l|}{ Churn } \\
\hline a (örebro material) & 4081 & $\begin{array}{l}\mathrm{CC}-\mathrm{CMT} \\
\mathrm{CC}-\mathrm{WsT}\end{array}$ \\
\hline b (Oslo material) & 732 & $\begin{array}{l}\mathrm{CC}-\mathrm{CMT} \\
\mathrm{CC}-\mathrm{BMR}\end{array}$ \\
\hline \multicolumn{3}{|l|}{ Weighing vessel } \\
\hline a & 1592 & $\begin{array}{l}\mathrm{CC}-\mathrm{CMT} \\
\mathrm{CC}-\mathrm{WsT} \\
\mathrm{CC}-\mathrm{CT}\end{array}$ \\
\hline b & $\begin{array}{l}37 \text { farms with }>8 \mathrm{CMT}+\text { reactions } \\
14 \text { farms with }>8 \mathrm{CMT}++ \text { reactions }\end{array}$ & $\begin{array}{l}\mathrm{CC}-\mathrm{CMT}+ \\
\mathrm{CC}-\mathrm{CMT}++\end{array}$ \\
\hline
\end{tabular}

ranges of variation were also revealed in the investigations of Schaaf et al. (1964).

Catalase Test. The existence of catalase in milk was demonstrated by Loew in 1901. Koning (1908) and Gratz \& Naray (1912), used the catalase test to detect mastitis.

Prouty (1934) investigated the extent to which CT reactions corresponded to the actual cell content, and reported a poor correlation within the limits of $2.5 \times 10^{5}-10 \times 10^{5}$ cells per ml. Much the same result was obtained by Andersen. Egli (1955) stated that the catalase tests after the methods of both Roeder and Koestler are not reliable for detecting the presence of mastitis in bulk milk with sufficient accuracy.

Correlation estimations. Spencer \& Simon (1960) gave the coefficients of correlation for CMT $-\mathrm{CC}$ as $\mathbf{0 . 7 1}$, and for CT - CC as 0.52. Postle \& Blobel investigated the correlation between cell content and the reactions of four different indirect tests. They obtained coefficients of 0.52 for CMT, 0.49 for WsT, 0.40 for BMR, and 0.27 for CT.

\section{MATERIAL}

The different comparisons carried out are shown in Table 1. In order to examine different types of samples, milk was collected from udder quarters, churns, and weighing vessels.

Samples from churns and weighing vessels were taken in the 
morning when the milk was weighed in at the respective dairies (Orebro and Oslo).

Besides the correlation BMR - CC, the correlation CMT - CC was also studied in the Oslo material for comparison with the Orebro material. A difference appeared in the average cell content, that for Orebro being $2 \times 10^{5}$ and that for Oslo $9 \times 10^{5}$ cells per $\mathrm{ml}$.

The churns contained evening's and/or morning's milk while the weighing vessels held the contents of up to five churns from both these milking times.

The mean cell value for a particular farm's CMT + or ++ reactions was calculated using weighing vessel samples from 39 different farms, each of which underwent 30 sample examinations during a period of 10 months (weighing vessel sample b). The mean cell value was calculated for farms having the same result in more than eight samples. For a + reaction this was the case on 37 farms, while a ++ reaction was obtained for 14 farms. The number of samples with negative or +++ reactions was too small to permit similar calculations.

\section{METHODS}

Careful mixing of milk in churns and weighing vessels was carried out before sample taking. A sample of about $40 \mathrm{ml}$ was taken in each case.

The milk was examined within $2 \mathrm{hrs}$. of sampling and was warmed to room temperature and carefully shaken immediately before testing.

Direct cell counting. The smear was prepared according to Prescott \& Breed (1910), while the method employed was described in an investigation of the accuracy of cell counting (Astermark 1969). $0.01 \mathrm{ml}$ milk was spread over an area of $1 \mathrm{~cm}^{2}$ with the aid of a microsyringe. The smear was stained with Newman's stain (Little \& Plastridge 1946). The total number of cells in 40 fields were counted under oil immersion. Two microscopes were used so that areas of $0.04526 \mathrm{~mm}^{3}$ and $0.03803 \mathrm{~mm}^{3}$ were examined. To obtain the number of cells per $\mathrm{ml}$ the figures obtained were multiplied by factors 22,100 and 26,300 respectively.

California Mastitis Test. The reagent used was a $5 \%$ solution of deterol (85-90\% water soluble alkylaryl-sulphonate). Equal volumes $(0.15 \mathrm{ml})$ of milk and reagent were mixed together by Thörne's mixer (1962) for about $10 \mathrm{sec}$. The gel formation was observed while the arms of the machine were in motion and the clot formation observed with the arms raised. 
The reactions were classified as follows:

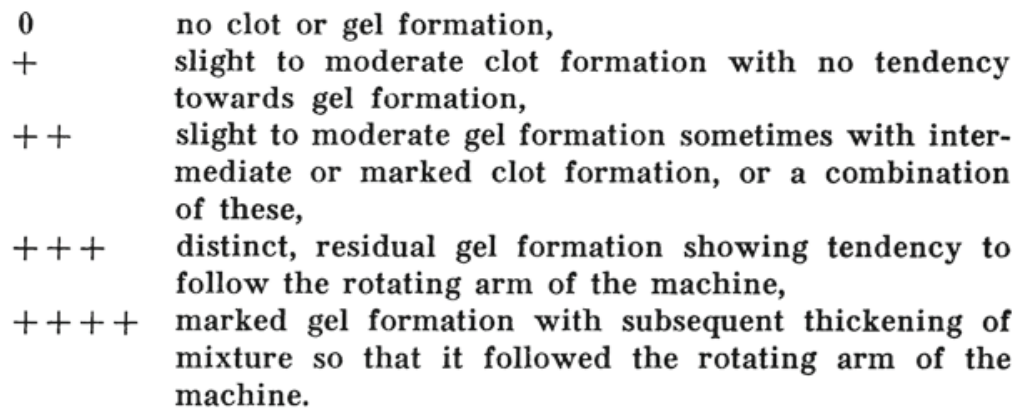

Whiteside Test. A drop of normal sodium hydroxide solution was mixed with 3 drops of milk with the aid of Thörne's mixer for about 20 sec. Gel formation was observed with the arms in motion and clot formation when they were raised.

The reactions were classified as follows:

0 no clot or gel formation,

$+\quad$ slight formation of small clots with no tendency towards coagulation,

++ distinct formation of large clots with a tendency towards coagulation, but without clearing of the mixture,

+++ weak, intermediate gel formation and/or distinct formation of large clots with obvious clearing of the mixture,

++++ gel formation with a considerable amount of large clots and clearing of the mixture.

Catalase Test. Ten $\mathrm{ml}$ milk was mixed with $5 \mathrm{ml}$ freshly prepared $1.5 \%$ hydrogen peroxide solution. The quantity of oxygen given off after $2 \mathrm{hrs}$. at room temperature was noted.

Brabant Mastitis Reaction. The apparatus and method described by Jaartsveld (1962) were employed. Five dots (....) denotes blocking of the capillary by clots.

Statistical calculations. The coefficients of correlation were calculated firstly using the whole material and secondly using samples with less than $10 \times 10^{5}$ cells per ml.

The number of cells in 40 fields was used as the $\mathrm{x}$ variable in the calculations and the different reactions of CMT, WsT, and BMR as the $y$ variable, signified by figures $0,1,2$, etc. For CT the catalase readings were placed together in $0.5 \mathrm{ml}$ groups signified by figures $0,1,2$, etc.

\section{RESULTS}

The mean cell values and standard deviations with different reactions of the indirect tests are presented in Table 2 . In all the tests employed there was a correlation between reaction and 
T a b le 2. Mean cell values and standard deviations for the different indirect test reactions.

\begin{tabular}{|c|c|c|c|c|c|c|c|c|c|c|c|c|c|}
\hline \multirow{3}{*}{ Test } & \multirow{3}{*}{ Reaction } & \multicolumn{12}{|c|}{ Cell content $\left(10^{5} / \mathrm{ml}\right)$} \\
\hline & & \multicolumn{3}{|c|}{$\begin{array}{l}\text { udder quarter } \\
\text { sample*) }\end{array}$} & \multicolumn{3}{|c|}{ churn sample (a)*) } & \multicolumn{3}{|c|}{$\begin{array}{l}\text { weighing vessel } \\
\left.\text { sample }(a)^{* *}\right)\end{array}$} & \multicolumn{3}{|c|}{ churn sample (b)*) } \\
\hline & & $\bar{x}$ & $\mathrm{~s}$ & $\mathrm{n}$ & $\bar{x}$ & $\mathrm{~s}$ & $\mathrm{n}$ & $\bar{x}$ & $\mathbf{s}$ & $\mathrm{n}$ & $\bar{x}$ & $\mathbf{s}$ & $\mathrm{n}$ \\
\hline \multirow{7}{*}{ CMT } & 0 & 1.0 & 1.0 & 483 & 1.1 & 1.1 & 1288 & 1.0 & 0.8 & 251 & 2.1 & 1.8 & 31 \\
\hline & + & 2.3 & 2.2 & 421 & 1.3 & 1.2 & 1831 & 1.3 & 0.9 & 847 & 2.3 & 1.3 & 56 \\
\hline & ++ & 4.8 & 3.2 & 149 & 3.5 & 2.4 & 678 & 3.0 & 1.7 & 370 & 4.4 & 2.4 & 269 \\
\hline & +++ & 26.1 & 35.0 & 407 & 8.5 & 6.2 & 284 & 7.6 & 5.5 & 124 & 12.8 & 10.9 & 366 \\
\hline & $+++t$ & 192.9 & 149.8 & 72 & & & & & & & 47.5 & 24.3 & 10 \\
\hline & 0 & & & & 0.9 & 2.1 & 424 & 1.0 & 0.9 & 93 & & & \\
\hline & + & & & & 1.1 & 1.0 & 1578 & 1.1 & 0.8 & 607 & & & \\
\hline \multirow[t]{6}{*}{ WsT } & ++ & & & & 2.2 & 2.2 & 1477 & 2.1 & 1.5 & 629 & & & \\
\hline & +++ & & & & 5.2 & 4.6 & 571 & 5.2 & 4.5 & 256 & & & \\
\hline & ++++ & & & & 11.4 & 7.1 & 31 & (8.9) & (3.5) & 7 & & & \\
\hline & 0 & & & & & & & & & & 5.6 & 4.5 & 540 \\
\hline & . & & & & & & & & & & 14.7 & 10.4 & 154 \\
\hline & . . & & & & & & & & & & 35.9 & 17.3 & 22 \\
\hline BMR & . . & & & & & & & & & & $(44.0)$ & $(30.0)$ & 8 \\
\hline & $\ldots$ & & & & & & & & & & $(29.0)$ & (21.8) & 4 \\
\hline & $\ldots \ldots$ & & & & & & & & & & (3.7) & $(2.1)$ & 4 \\
\hline
\end{tabular}

*) Factor 26,300. ${ }^{* *}$ ) Factor 22,100.

mean cell content for samples from udder quarters, churns, and weighing vessels. The mean cell values for different reactions of CMT and WsT in the Orebro material are almost consistent between different types of bulk milk samples (i.e. from churns and weighing vessels), but lie at a higher level for udder samples. When the Orebro and Oslo materials are compared, the mean cell values are higher for the different CMT reactions in the latter material.

Standard deviations of cell content for the indirect test reactions (Table 2) were large. This was, however, partly due to the fact that the values for cell content were not real, but estimated values. These can be corrected by the formula $\sigma=\frac{n-1}{n}\left(s^{2}-\bar{x}\right)$. (Nilsson 1964), where $\mathrm{n}$ is the number of samples with a given reaction, $\mathrm{s}^{2}$ the variance before correction, $\overline{\mathrm{x}}$ the mean and $\sigma$ the standard deviation after correction. This correction brings about only a slight reduction of the values for standard deviation given in Table 2. 


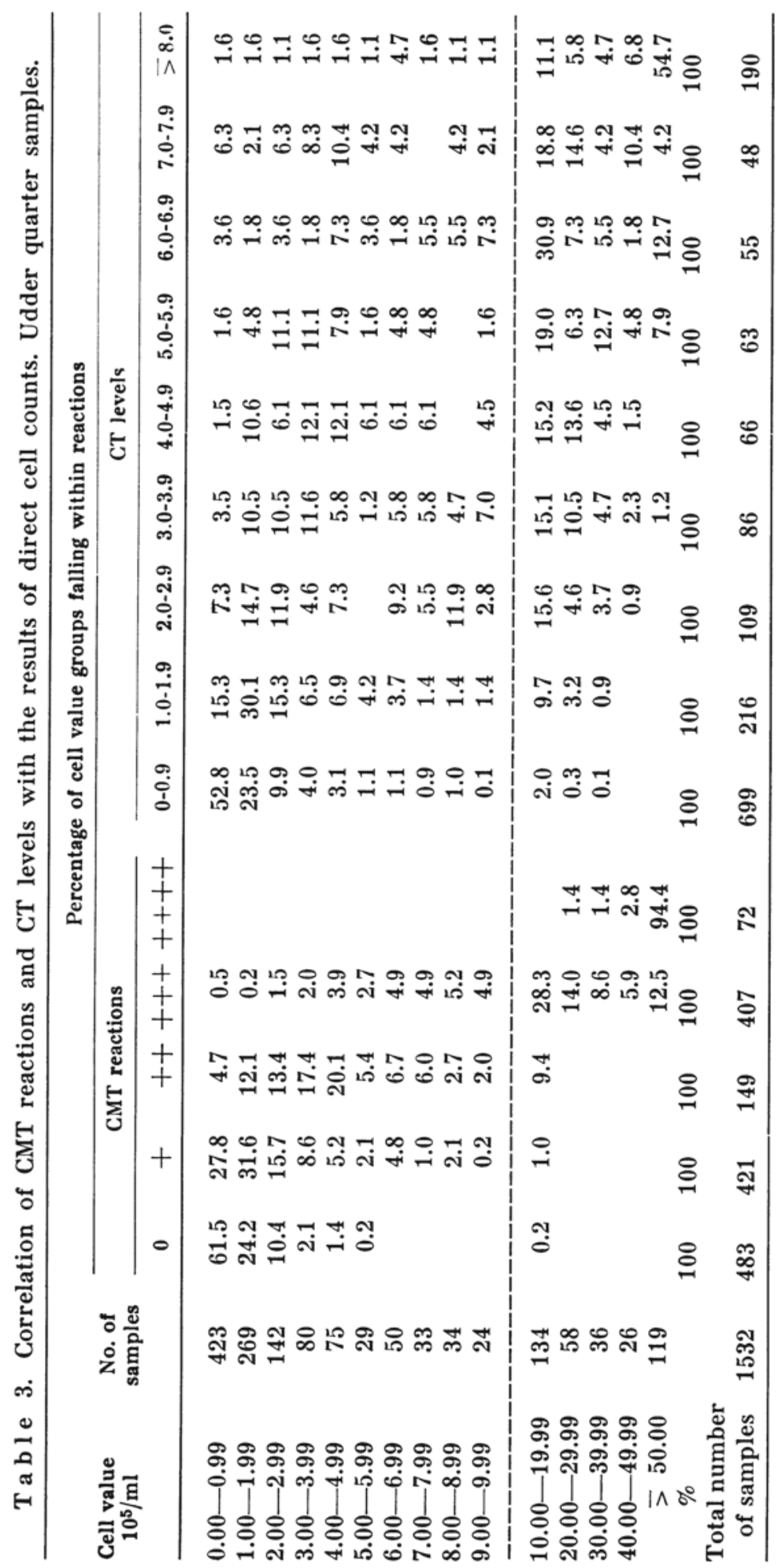


T a b l e 4. Correlation of CMT and WsT with the results of direct cell counts. Churn samples (a).

\begin{tabular}{|c|c|c|c|c|c|c|c|c|c|c|}
\hline \multirow{3}{*}{$\begin{array}{l}\text { Cell value } \\
10^{5} / \mathrm{ml}\end{array}$} & \multirow{3}{*}{$\begin{array}{c}\text { No. of } \\
\text { samples }\end{array}$} & \multicolumn{9}{|c|}{ Percentage of cell value groups falling within reactions } \\
\hline & & \multicolumn{4}{|c|}{ CMT reactions*) } & \multicolumn{5}{|c|}{ Ws $T$ reactions } \\
\hline & & 0 & + & ++ & +++ & 0 & + & ++ & +++ & ++++ \\
\hline $0.00-0.99$ & 1575 & 54.6 & 44.0 & 9.6 & 0.7 & 67.7 & 53.9 & 26.8 & 7.4 & \\
\hline $1.00-1.99$ & 1148 & 28.5 & 34.8 & 19.5 & 4.2 & 25.0 & 31.1 & 32.0 & 13.5 & 6.5 \\
\hline $2.00-2.99$ & 560 & 11.0 & 13.5 & 21.5 & 8.5 & 4.5 & 10.5 & 19.2 & 15.8 & 3.2 \\
\hline $3.00-3.99$ & 292 & 3.3 & 5.1 & 18.3 & 11.3 & 1.7 & 3.5 & 9.3 & 15.8 & 3.2 \\
\hline $4.00-4.99$ & 155 & 1.4 & 1.3 & 12.1 & 10.9 & 0.5 & 0.3 & 6.3 & 9.3 & 6.5 \\
\hline $5.00-5.99$ & 78 & 0.7 & 0.5 & 5.2 & 8.8 & & 0.3 & 1.9 & 7.7 & 3.2 \\
\hline $6.00-6.99$ & 84 & 0.3 & 0.4 & 6.6 & 9.9 & & 0.2 & 2.2 & 8.1 & 6.5 \\
\hline $7.00-7.99$ & 39 & 0.1 & 0.2 & 2.5 & 6.3 & 0.2 & 0.1 & 0.4 & 5.3 & 3.2 \\
\hline $8.00-8.99$ & 31 & & 0.1 & 1.8 & 6.3 & & & 0.6 & 3.3 & 9.7 \\
\hline $9.00-9.99$ & 29 & & 0.1 & 1.2 & 6.7 & & & 0.3 & 3.5 & 9.7 \\
\hline$>10.00$ & 90 & 0.2 & 0.1 & 1.8 & 26.4 & 0.5 & 0.1 & 0.9 & 10.5 & 48.4 \\
\hline$\%$ & & 100 & 100 & 100 & 100 & 100 & 100 & 100 & 100 & 100 \\
\hline $\begin{array}{c}\text { Total number } \\
\text { of samples }\end{array}$ & 4081 & 1288 & 1831 & 678 & 284 & 424 & 1578 & 1477 & 571 & 31 \\
\hline
\end{tabular}

*) CMT reaction ++++ did not occur in this material.

The relation between the indirect tests and cell values is shown in Tables $3-6$. The cell values were divided into classes with the ranges $1 \times 10^{5}$ and $10 \times 10^{5}$ according to whether the values were lower or higher than $10 \times 10^{5}$. The distribution of cell values within the different reactions for CMT, WsT, BMR and CT have not a normal, but a markedly skew distribution which is particularly evident in the lower reactions. The variation of cell content within a given reaction is very large. This is further evident from the standard deviations as stated above. Negative and + reactions for CMT and WsT had the narrowest ranges of variation.

These large variations in cell content result to a large extent in the values' overlapping one another for different reactions. This is particularly true for CT and the two lowest BMR reactions. The limits for cell values between reactions therefore cannot be fixed, but a certain gradation of the upper limit of the variation ranges can be observed with increasing reactions for WsT and CMT. Exceptions to this are + and ++ reactions for udder quarter samples (Table 3), where the upper limits of cell content variations generally rose to the same cell levels. WsT of 


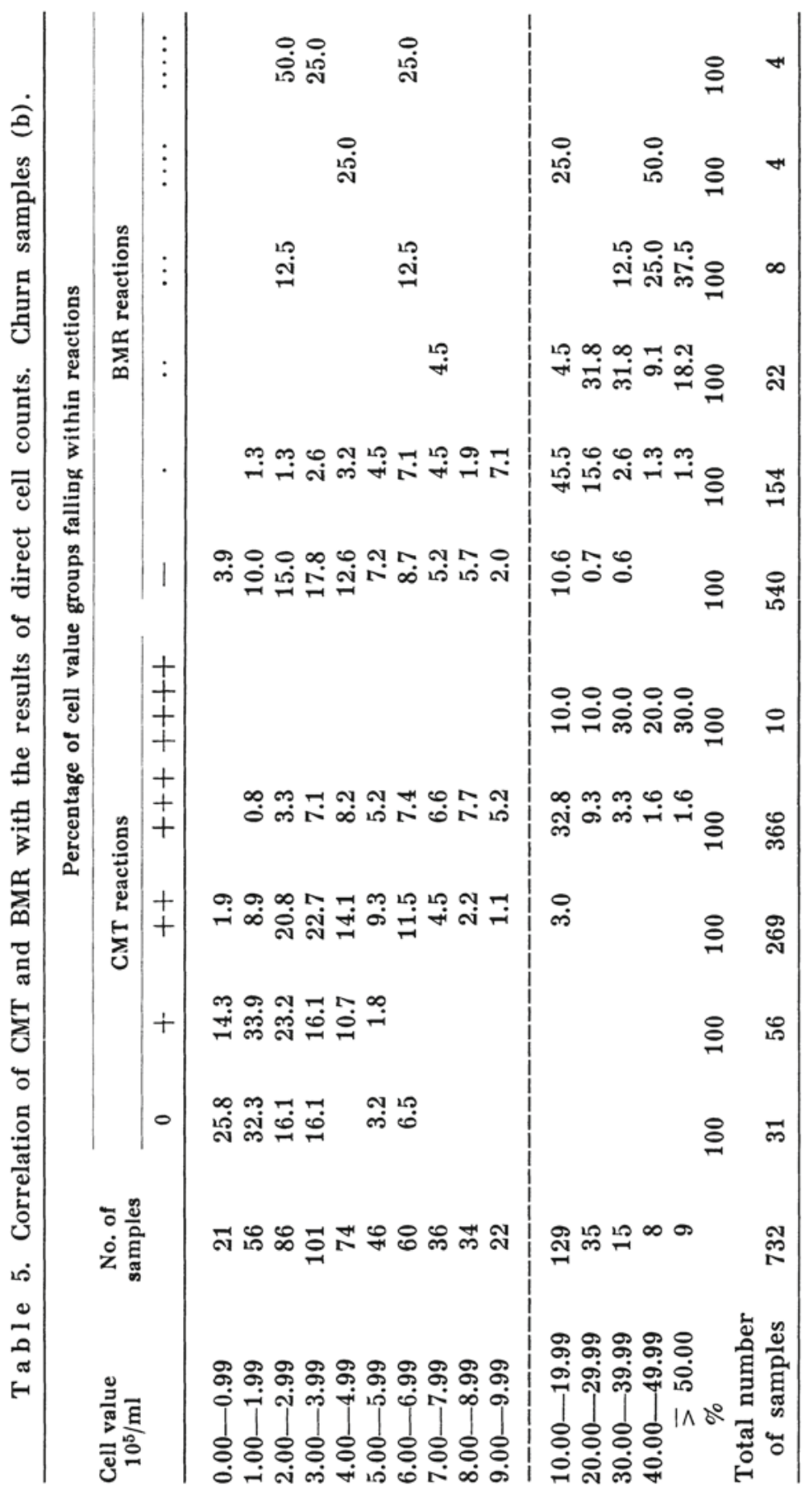




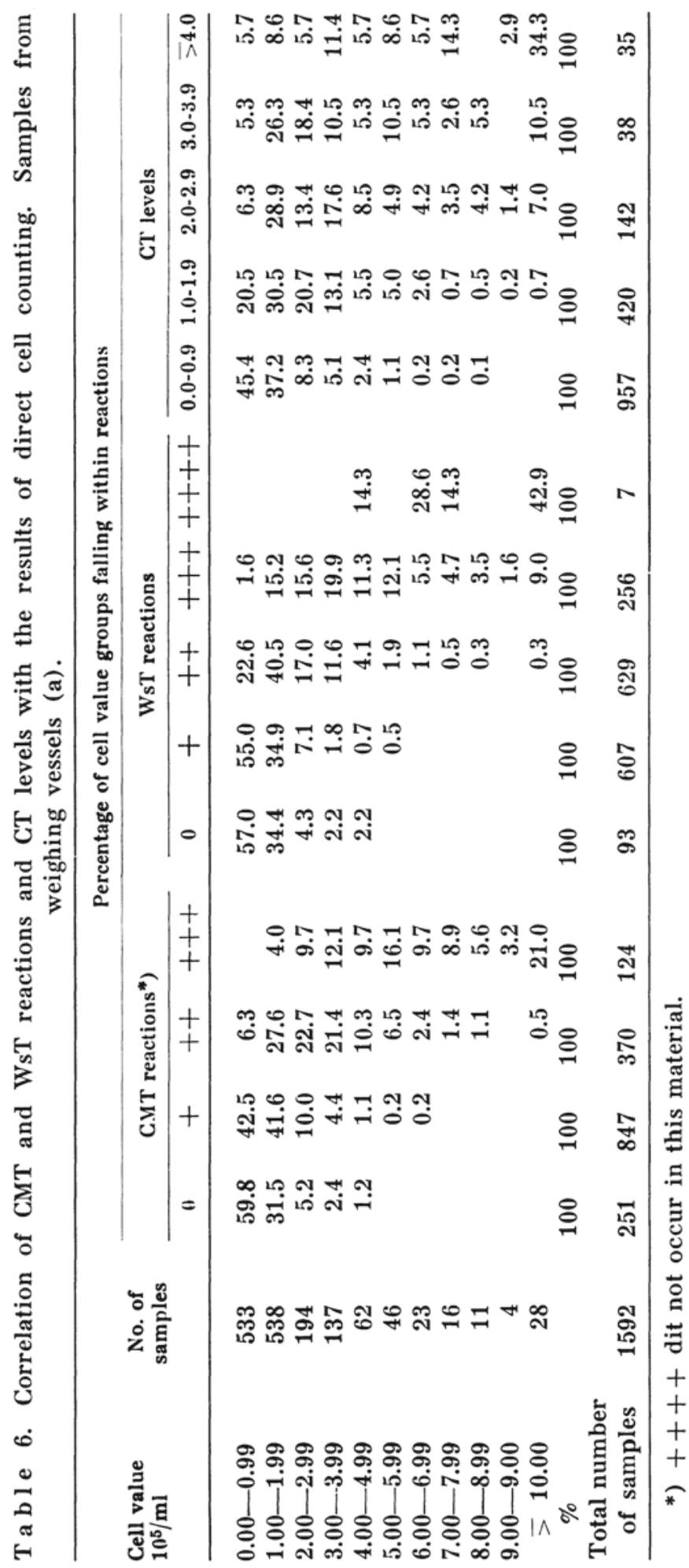


T a ble 7. Coefficients of correlation for relations between different tests.

\begin{tabular}{|c|c|c|c|c|c|c|c|c|}
\hline \multirow{3}{*}{ Test } & \multicolumn{8}{|c|}{ Coefficients of correlation } \\
\hline & \multicolumn{2}{|c|}{$\begin{array}{l}\text { udder quarter } \\
\text { samples }\end{array}$} & \multicolumn{2}{|c|}{ churn samples (a) } & \multicolumn{2}{|c|}{$\begin{array}{l}\text { weighing vessel } \\
\text { samples (a) }\end{array}$} & \multicolumn{2}{|c|}{ churn samples (b) } \\
\hline & $\begin{array}{c}\text { total } \\
\text { material }\end{array}$ & $\begin{array}{c}<10 \times 10^{5} \\
\text { cells }\end{array}$ & $\begin{array}{c}\text { total } \\
\text { material }\end{array}$ & $\begin{array}{c}<10 \times 10^{5} \\
\text { cells }\end{array}$ & $\begin{array}{c}\text { total } \\
\text { material }\end{array}$ & $\begin{array}{c}<10 \times 10^{5} \\
\text { cells }\end{array}$ & $\begin{array}{c}\text { total } \\
\text { material }\end{array}$ & $\begin{array}{c}<10 \times 10^{5} \\
\text { cells }\end{array}$ \\
\hline $\mathrm{CMT}-\mathrm{CC}$ & 0.47 & 0.72 & 0.56 & 0.56 & 0.59 & 0.63 & 0.48 & 0.55 \\
\hline $\mathrm{WsT}-\mathrm{CC}$ & & & 0.48 & 0.52 & 0.51 & 0.57 & & \\
\hline CT - CC & & 0.53 & & & 0.54 & 0.45 & & \\
\hline $\mathrm{BMR}-\mathrm{CC}$ & & & & & & & 0.56 & 0.13 \\
\hline
\end{tabular}

bulk milk samples revealed only a small number of samples with + reactions which had cell values of $3 \times 10^{5}$ or higher, or ++ reactions which had cell values of $5 \times 10^{5}$ or higher. The corresponding values for CMT are $3-4 \times 10^{5}$ and $6-8 \times 10^{5}$ respectively for bulk milk samples. For BMR the upper limit for negative reactions was in the region of $10-20 \times 10^{5}$. For CT there were no great differences between the upper limits for different reactions.

The coefficients of correlation (Table 7) are somewhat higher for the CMT - CC correlation than for the others except in the Oslo material, where BMR had a larger coefficient than CMT, i.e. 0.56 against 0.48 . In samples with a figure of less than $10 \times 10^{5}$ cells per ml CMT - CC had the highest coefficient throughout. In the Oslo material the coefficient in this interval was 0.13 for BMR - CC against 0.55 for CMT - CC.

Comparison of the churn samples in the orrebro material (mean cell content $2 \times 10^{5}$ ) (Table 4) and the Oslo material (mean cell content $9 \times 10^{5}$ ) (Table 5), shows that in the former $8.6 \%$ of the samples contain more than $5 \times 10^{5}$ cells per ml against $53.8 \%$ in the latter. In both sets of material the ranges of variation are generally equally large, and partly overlap one another, but in the group of samples with the higher cell average, the majority of the samples are inclined to have higher cell values for the reactions ++ and +++ , and these reactions therefore have higher mean cell contents than the group of samples with the lower cell average. The coefficient of correlation is somewhat lower for the Oslo material when using the total material, but is generally the same for samples of less than $10 \times 10^{5}$ cells. 
T a b le 8. Mean cell number for CMT reaction + and ++ within farms. Weighing vessel samples (b).

\begin{tabular}{|c|c|c|c|c|c|c|c|c|c|}
\hline \multirow[b]{2}{*}{$\begin{array}{l}\text { Farm } \\
\text { no. }\end{array}$} & \multicolumn{2}{|c|}{ CMT reaction +} & \multicolumn{2}{|c|}{ CMT reaction ++} & \multirow[b]{2}{*}{$\begin{array}{l}\text { Farm } \\
\text { no. }\end{array}$} & \multicolumn{2}{|c|}{ CMT reaction +} & \multicolumn{2}{|c|}{ CMT reaction ++} \\
\hline & $\begin{array}{c}\text { no. of } \\
\text { samples }\end{array}$ & $\begin{array}{c}\text { mean } \\
10^{3} / \mathrm{ml}\end{array}$ & $\begin{array}{c}\text { no. of } \\
\text { samples }\end{array}$ & $\begin{array}{c}\text { mean } \\
10^{3} / \mathrm{ml}\end{array}$ & & $\begin{array}{c}\text { no. of } \\
\text { samples }\end{array}$ & $\underset{10^{3} / \mathrm{ml}}{\operatorname{mean}}$ & $\begin{array}{c}\text { no. of } \\
\text { samples }\end{array}$ & $\begin{array}{c}\text { mean } \\
10^{3} / \mathrm{ml}\end{array}$ \\
\hline 14 & 19 & 119 & & & 34 & 14 & 133 & & \\
\hline 15 & 13 & 184 & 8 & 401 & 35 & 21 & 100 & & \\
\hline 16 & 14 & 96 & 12 & 203 & 36 & 20 & 108 & & \\
\hline 17 & 24 & 52 & & & 37 & 16 & 122 & 8 & 304 \\
\hline 18 & 10 & 88 & & & 38 & 21 & 124 & & \\
\hline 19 & 17 & 146 & 11 & 358 & 39 & 19 & 112 & & \\
\hline 20 & 13 & 175 & 9 & 295 & 40 & & & 14 & 377 \\
\hline 21 & 11 & 185 & 12 & 249 & 41 & 10 & 166 & & \\
\hline 22 & 11 & 247 & 10 & 367 & 42 & & & 13 & 362 \\
\hline 23 & 21 & 141 & & & 43 & 20 & 102 & & \\
\hline 24 & 15 & 115 & 10 & 477 & 44 & 20 & 109 & & \\
\hline 25 & 13 & 206 & 10 & 343 & 45 & 24 & 107 & & \\
\hline 26 & 17 & 188 & & & 46 & 23 & 137 & & \\
\hline 27 & 21 & 109 & & & 47 & 20 & 124 & & \\
\hline 28 & 20 & 115 & & & 48 & 16 & 156 & & \\
\hline 29 & 21 & 149 & & & 49 & 15 & 169 & 13 & 258 \\
\hline 30 & 15 & 138 & & & 50 & 37 & 88 & & \\
\hline 31 & 15 & 84 & & & 51 & 69 & 117 & 32 & 252 \\
\hline 32 & 19 & 165 & & & 52 & 41 & 183 & 70 & 260 \\
\hline 33 & 11 & 189 & & & & & & & \\
\hline
\end{tabular}

In 37 herds the mean cell values for CMT + reactions varied from 52,000 to 247,000 and in 14 herds for ++ reactions they varied from 203,000 to 477,000 cells per ml (Table 8). The median test (Dixon \& Massey 1957) revealed highly significant differences between farms for both reactions.

Comparison between samples from udder quarters, churns and weighing vessels (Tables 2-6) did not reveal any fundamental differences in the distribution of cell values within reactions. The most noteworthy difference was that the upper limits of the range for + and ++ reactions generally reached the same level in udder samples, which was in contrast to bulk milk samples. 


\section{DISCUSSION}

Comparison shows that there is a correlation between indirect test reactions and cell values. Comparison of material with different average cell contents, however, shows that one and the same CMT reaction does not consistently detect samples containing the same average cell content. Moreover, transitions between reactions cannot be fixed, and even if there are certain ill-defined limits, the cell values of the different reactions partly overlap one another. Thus milk samples containing cell contents within certain limits, do not necessarily conform to a particular reaction in any test.

The ranges of variation and the standard deviations for different reactions are large and the standard deviations rise with the mean cell content. Large standard deviations were also reported by Leidl \& Schalm (1961) and Baier (1964). The two lowest reactions for CMT and WsT had, in contrast to BMR, relatively low cell levels, the majority lying below $3 \times 10^{5}$ cells per ml. For CT levels under 1.0 most of the samples had relatively low cell values, but the results were not so reliable as those of CMT and WsT.

Because of large variation ranges for CMT and WsT ++ and +++ reactions, not only samples with a relatively high cell content, but also a high percentage with low cell levels occurred within these reactions. For CMT ++ reactions between 68 and $88 \%$ of the total material contained less than $5 \times 10^{5}$ cells per $\mathrm{ml}$, while for +++ reactions the figure was between 8 and $36 \%$. The corresponding figures for WsT were approximately 95 and $63 \%$. For CT levels above 1.0 the correlation is poor, and for BMR only $5 \%$ of the samples produced a reaction stronger than one dot. The latter thus fails to differentiate between samples with a cell content of less than one million.

The standard deviation for different reactions is large, and although this could partly be attributed to the fact that cell levels are merely estimations of the real value, a correction for this produces practically no reduction. For example for CMT ++ reactions in samples from weighing vessels the standard deviation falls only from 1.7 to $1.5 \times 10^{5}$, and for +++ reactions from 5.5 to $5.3 \times 10^{5}$ cells per ml. Although the reduction is greater for a larger quantity of milk examined in each sample, the difference between the standard deviation for the estimated and real values remains small. It is also possible that the wide 
ranges of variation may be partly due to substances other than those confined to the cells combining with the reagent. The mechanism of these tests, as mentioned in the review of the literature, is not completely clear.

The coefficients of correlation were calculated, firstly for the total material and secondly for samples containing less than $10 \times 10^{5}$ cells per $\mathrm{ml}$, since a correlation below this level appears to be of greatest interest in Sweden in view of an eventual routine examination of cell content in bulk milk.

Because of the marked skew distribution through the material, differences between the coefficients of correlation could not be tested. From the numerical values of the coefficients, however, it is evident that they were larger in the Orebro material for the correlation CMT - CC than for either WsT - CC or CT CC, both for weighing vessel and churn samples. This corresponds with the values obtained by Spencer \& Simon (1960) and Postle \& Blobel (1965). In contrast to the other indirect tests, CT gives a quantitative variable and should therefore result in a higher coefficient of correlation if the tests are of equal value.

Comparison of coefficients of correlation for CMT - CC and $\mathrm{BMR}$ - CC in the Oslo material revealed that BMR produces a more reliable numerical value than CMT when the total material is included. In samples containing less than $10 \times 10^{5}$ cells per ml the coefficient of correlation for BMR - CC was only 0.13 so that no correlation was apparent here. For CMT - CC the coefficient, however, was 0.55 and thus of a similar value as in the Orebro material.

A comparison of the coefficients of correlation for all samples regardless of cell content, with those possessing less than $10 \times 10^{5}$ cells per $\mathrm{ml}$, reveals that the differences for samples from weighing vessels and churns is small while there was a large difference for the udder quarter samples. This is because the majority of weighing vessel and churn samples contained less than $10 \times 10^{5}$ cells per ml, while the udder samples included a higher percentage of samples of high cell level which could not be labelled with a higher reaction than ++++ , irrespective of how high the cell level actually was. The coefficients of correlation were therefore lower for material containing a large percentage of high cell values. The low coefficient of correlation for BMR for samples lying below $10 \times 10^{5}$ cells per $\mathrm{ml}$ is due to the fact that BMR differentiates samples among the high cell levels, so that 
most samples containing less than $10 \times 10^{5}$ cells per ml come to lie within the lowest reaction.

Using the coefficients of correlation to compare the indirect tests for these cell levels, CMT appears a little more reliable than WsT (although the difference is small) and certainly more reliable than CT and BMR.

The situation regarding udder health, hence cell content in bulk milk, varies with different farm groups. Comparing material with a low mean cell content (calculated from the total number of samples) and material with a higher mean cell content, the means for individual reactions are also higher in the former. One cannot therefore simply apply the results of one material to another.

Although the ranges for a reaction are wide, different farms in a series of samples with the same reaction could have mean cell values of approximately the same order. However, the comparison which was carried out reveals that there are considerable differences in mean cell values for CMT + reactions on different farms. This is also true for ++ reactions.

It is thus evident that a given reaction does not have the same mean cell value in all material and that standard deviations and range variations are large, the latter overlapping one another to a great extent. It is therefore not acceptable to merely replace the different reactions of the various tests with a single mean value for cell level. The possibility of substituting the two lowest reactions of CMT and WsT by a mean could be considered. Moreover, whether a sample is accepted or rejected should not be based entirely on an indirect test, if this means that for inacceptable samples the cell content exceeds a certain level. In practice consideration must be given to the aim of the actual investigation.

There exists, however, the possibility of combining the indirect test with cell counting. Using the indirect test, samples with low reactions could be passed while those with higher reactions could be examined by cell counting. Such a possibility will be further discussed in a subsequent paper (Astermark et al. 1969).

Beyond the previously mentioned, uneven distribution within reactions, due to different total mean cell content in the material, comparison between udder quarter, churn, and weighing vessel samples indicates no other fundamental difference except that 
the variation ranges for + and ++ reactions in udder samples generally attain the same level of cell content. It was noticed that for CMT readings the degree of precipitation was difficult to estimate in very fresh milk, especially with a high butter fat content. This could be a contributing factor towards the fact that no difference was observed between these reactions.

\section{REFERENCES}

Andersen, F.: Unders $\varnothing$ gelser over Whitesidepr $\varnothing$ vens anvendelighed i mælkekontrollen. (Studies of the applicability of the Whiteside Test on milk samples). Nord. Vet.-Med. 1957, 9, 191-209.

Astermark, S.: Studies in direct cell counting in herd bulk milk. Nord. Vet.-Med. 1969, 21, 23-36.

Astermark, S., H. Funke \& G. Nilsson: 1969. In press.

Baier, W.: Der Schalm-Mastitis-Test in der planmässigen Euterkontrolle. (The Schalm Mastitis Test in organized udder health control). Wien. tierärztl. Mschr. 1964, 51, 11-17.

Barnum, D. A.\& F. H. S. Newbould: The use of the California mastitis test for the detection of bovine mastitis. Canad. vet. J. 1961, 2, $83-90$.

Carroll, E. J. \& O. W. Schalm: Effect of deoxyribonuclease on the California test for mastitis. J. Dairy Sci. 1962, 45, 1094-1097.

Daniel, R. C. W., G. C. Smith \& D. A. Barnum: The relationship of California mastitis test (C.M.T.) scores with leucocyte counts on bucket milk samples. Canad. vet. J. 1966, 7, 80-83.

Dedié, K. \& G. Kielwein: Alkylarylverbindungen als Reagens zur Ermittlung von Sekretionsstörungen des Euters beim Rind. (Alkylaryl compounds as reagents in the detection of bovine udder affections). Rindertuberkulose $1960,9,19-27,35-43$.

Dixon, W. J. \& F. J. Massey: Introduction to Statistical Analysis, 2nd Ed. McGraw-Hill Book Co. New York, Toronto and London 1957, p. 296.

Dunn, H. O., J. M. Murphy \& O.F. Garrett: Nature of the material in milk responsible for the modified Whiteside test for mastitis. J. Dairy Sci. 1943, 26, 295-303.

Easterday, B. C., J. Simon \& R. P. Hanson: The use of the modified Whiteside test as a screen test for bovine mastitis. J. Amer. vet. med. Ass. 1958, 133, 470-473.

Egli, R.: Nachweis euterkranker Milch aus Lieferantenproben. (Detection of mastitis in producer milk samples). Inaugural-Diss., Bern, Schaffhausen 1955.

Ewbank, R.: An evaluation of the California mastitis test and the Negretti field test as indicators of subclinical bovine mastitis. Vet. Rec. 1962, 74, 1017-1020.

Gram, H. J.\& J. O. Marker: Celletællingens og teepolprøvens værdi til påvisning af abnormt sekret i leverandørmælk. (Evaluation of cell counts and teepoltests as means of demonstrating abnormal 
secretion in producer's milk). Nord. Vet.-Med. 1959, 11, 681708.

Gratz, O. W. \& A. Naray: 1912, as cited by Monlux, A. W.: 1948.

Jaartsveld, F. H. J.: Bijdrage tot de diagnostiek van mastitis bij runderen in het kader van een georganiseerde bestrijding. (Contribution to the diagnosis of bovine mastitis within the scope of an organized eradication). Proefschrift, Breukelen, Utrecht 1961.

Jaartsveld, F. H. J.: Execution and value of the B.M.R. (Brabant Mastitis Reaction) with an organized mastitis control. T. Diergeneesk. 1962, 87, 1069-1077.

Jensen, P. T.: Unders $\varnothing$ gelser over Whiteside-pr $\varnothing$ ven og C.M.T.-pr $\varnothing v e n$ til påvisning af mastitissekret i leverandørmælk. (Investigations into the Whiteside-test and the C.M.T.-test for the detection of pathological secretions in herd milk samples). Nord. Vet.-Med. 1957, 9, 590-608.

Klein, H. \& H. J. Thomas: Erfahrungen mit dem Schalm-Mastitis-Test. (Report on the Schalm-Mastitis-Test). Berl. Münch. tierärztl. Wschr. 1962, 75, 44-47.

Koning, C. J.: 1908, as cited by Monlux, A. W.: 1948.

Kästli, P.: Schnellmethoden zum Nachweis euterkranker Milch. (Rapid methods to detect anomalies of milk (mastitis milk)). Schweiz. Milchztg. 1963, 89, 693-700.

Leidl, W. \& O. W. Schalm: Die Anwendung des Schalm-Mastitis-Testes (SMT) bei Sammelmilch zur Bestimmung minderwertiger Milch, bedingt durch hohen Zellgehalt. (The application of Schalm Mastitis Test to bulk milk for the determination of low quality milk due to high cell count). Tierärztl. Umsch. 1961, 16, 219222.

Leidl, W., O. W. Schalm, A. Krieger \& H. Lagemann: Vergleich des Schalm-Mastitis-Testes mit dem Zellgehalt, der Katalase-Thybromol-Probe und dem Chlorgehalt in der Milch. (Comparison of Schalm-Mastitis-Test with the cell count, Catalase-ThybromolTest, and the chloride content of the milk). Berl. Münch. tierärztl. Wschr. 1961, 7/, 382-384.

Little, R. B. \& W. N. Plastridge: Bovine Mastitis. McGraw-Hill Co., New York and London 1946.

Loew, O., 1901, as cited by Monlux, A. W.: 1948.

McKenzie, D. A. \& E. Cameron-Mackintosh: A simple test for the detection of subclinical mastitis using the surface active agent teepol. J. Soc. Dairy Technol. 1958, 11, 178-180.

Miller, D. D. \& J. V. Kearns: Effectiveness of the California mastitis test as a measurement of the leucocyte content of quarter samples of milk. J. Dairy Sci. 1967, 50, 683-686.

Monlux, A. W.: The catalase test in the diagnosis of infectious bovine mastitis. Cornell Vet. 1948, 38, 389-405.

Murphy, J. M. \& J. J. Hanson: A modified Whiteside test for the detection of chronic bovine mastitis. Cornell Vet. 1941, 31, 47-55.

Nilsson, G.: Personal communication, 1964. 
Obiger, G.: Der Wert des Whiteside-Testes im Rahmen der MastitisDiagnose. (The value of the Whiteside test in the diagnosis of mastitis). Berl. Münch. tierärztl. Wschr. 1957, 70, 290-292.

Obinger, G.: Warum ist der Schalm-Test kein zuverlässiges MastitisDiagnostikum? Versuch einer Deutung seines Wirkungsmechanismus. (Why is the Schalm Test not a reliable diagnostic method for mastitis? An attempt to illustrate its mechanism). Arch. Lebensmitt.-Hyg. 1961, 12, 226-233.

Petersen, E.: Nogle unders $\varnothing$ gelser over „Whiteside-Pr $\varnothing$ ven“ med særligt henblik på dens anvendelse i den praktiske mælkekontrol. (Studies on the "Whiteside Test" with special reference to its employment in practical milk control). Nord. Vet.-Med. 1952, 4, $225-240$.

Petersen, W. E., J. F. Grimmell \& I. A. Schipper: Factors involved in the Whiteside reaction. J. Dairy Sci. 1950, 33, 384.

Postle, D. S. \& H. Blobel: Studies of bulk milk screening procedures for mastitis. Amer. J. vet. Res. 1965, 26, 90-96.

Prescott, S. C.\& R. S. Breed: The determination of the number of body cells in milk by a direct method. J. infect. Dis. 1910, 7, 632-640.

Prouty, C. C.: A comparison of the leucocyte count, the brom thymol blue reaction and the catalase content of freshly drawn milk. J. Dairy Sci. 1934, 17, 75-83.

Schaaf, A. van der, F. H. J. Jaartsveld \& A. Kramer-Zeeuw: Influence of $\mathrm{pH}$ and temperature on the Brabant mastitis reaction (B.M. R.). J. comp. Path. 1964, 74, 255-262.

Schalm, O. W. \& D. O. Noorlander: Experiments and observations leading to development of the California mastitis test. J. Amer. vet. med. Ass. 1957, 130, 199-204.

Schultze, W. D. \& J. W. Smith: The cellular content of cows milk. II. Comparison of the CMT and microscopic count for estimating cell concentrations in quarter samples. J. Milk Food Technol. 1966, 29, 126-129.

Smith, J. W. \& W. D. Schultze: The cellular content of cows milk. I. An evaluation of the California mastitis test as a method of estimating the number of cells in milk. J. Milk Food Technol. 1966, 29, 84-97.

Spencer, G. R. \& J. Simon: The catalase, California, and cell count tests for detecting abnormalities in milk. Amer. J. vet. Res. 1960, 21, 578-584.

Strozzi, F.\& F. Negretti: Valore e limiti della prova di Whiteside nell'esame citologico del latte. (The value and limits of the Whiteside test in the cytological examination of milk). Arch. vet. ital. 1959, 10, 311-318.

Thörne, H.: Ein automatischer Apparat in der Mastitisdiagnostik. (An automatic apparatus for use in mastitis diagnosis). Berl. Münch. tierärztl. Wschr. 1962, 75, 47-48.

Whiteside, W. H.: Observations on a new test for the presence of mastitis in milk. Canad. publ. Hlth J. 1939, 30, 44. 


\section{SUMMARY}

The aim of this work was to study the relationship between the reactions obtained by indirect methods of testing milk samples and the cell content, determined by direct cell counting after Prescott \& Breed (1910). The indirect tests used were the California Mastitis Test (CMT), Whiteside Test (WsT), Brabant Mastitis Reaction (BMR), and the Catalase Test (CT).

The results of the investigations are summarized below.

Samples with cell values lying within fixed limits do not necessarily conform to particular indirect test reactions.

All four indirect tests have wide ranges of variation of cell level within a given reaction with considerable overlapping between reactions.

The standard deviation for cell levels within a given reaction is large, although this can be partly explained by the fact that the cell values are estimated rather than real. Correction for this produces only an insignificant decrease, however.

The coefficient of correlation is a little higher for the correlation CMT-CC than for the other indirect tests and CC.

When sample groups with different mean cell levels (calculated from the whole material) are compared, the variation ranges (difference between the largest and the smallest observation) and standard deviations are generally the same for the different CMT reactions. However, the mean cell values, for different reactions lie at higher levels when the mean cell content of the whole material is higher. Similarly they are lower when the mean of the whole material is lower. This is, however, not true for 0 reactions.

The mean cell values for CMT + and for ++ reactions varied considerably in different herds.

It was not considered acceptable, for any of the four indirect tests, to substitute reactions by average cell values, either to determine the mean cell value or to decide whether a sample is inacceptable, if this means that the sample has a cell content above a certain value.

Negative and + reactions for CMT and WsT could possibly be replaced by a mean cell level, since the range of variation is not so wide here and the majority of samples giving these reactions contain less than $3 \times 10^{5}$ cells per ml.

The possibility exists of combining indirect tests and direct cell counting to examine milk samples, so that samples with low reactions could be passed, while those with higher reactions would be examined by cell counting.

The indirect tests differentiate milk at different cell levels. The possibility of using a particular indirect test depends on the cell level to be examined and on the degree of accuracy required. 


\section{ZUSAMMENFASSUNG}

Das Verhältnis zwischen California Mastitis Test, Whiteside Test, Brabant Mastitis Reaktion, Katalase-Test und direkter Zählung der Zellen in der Milch.

Die Absicht mit der Untersuchungen ist gewesen, den Zusammenhang zwischen den Zellgehaltsberechnungen in Milch bei den indirekten Testmethoden California Mastitis Test (CMT), Whiteside Test (WsT), Brabant Mastitis Reaktion (BMR), Catalase Test (CT) und dem Zellgehalt, festgestellt durch direkte Zellgehaltsberechnung (CC) nach Prescott \& Breed (1910) zu studieren.

Die Untersuchungen haben folgendes gezeigt:

Proben mit Zellgehalten innerhalb festgesetzten Zellgehaltsgrenzen stimmen nicht immer mit dem Ergebnis der indirekten Teste überein.

Sämtliche indirekte Teste hatten grosse Variationsbreiten des Zellgehaltes innerhalb der verschiedenen Ausfälle mit grosser Deckung über die Resultatgrenzen.

Die Standardabweichung der Zellgehaltsberechnungen innerhalb der verschiedenen Ausfälle ist gross, aber zum Teil kann dieses Verhältnis dadurch erklärt werden, dass die Werte nur geschätzt sind. Korrektion hierfür gibt jedoch nur einen minimalen Ausgleich.

Der Korrelationskoeffizient ist etwas höher zwischen CMT und CC als zwischen den übrigen indirekten Tests und CC.

Wenn die Probepopulationen mit verschiedenen Durchschnittszellgehalten verglichen werden, sind die Variationsbreiten und die Standardabweichungen ungefähr dieselben für die verschiedenen CMT-Ausfälle. Die Durchschnittszellgehaltswerte für verschiedene Reaktionen sind jedoch höher, wenn die Durchschnittswerte in dem ganzen Material höher sind, im Vergleich zu einem Material mit niedrigen Zellgehaltswerten. Dieses gilt jedoch nicht für den Ausfall 0.

Durchschnittszellgehalte für die CMT-Ausfälle + und ++ haben in verschiedenen Herden innerhalb weiter Grenzen variiert.

Für alle indirekten Teste gilt, dass man es nicht für korrekt halten kann die Ausfälle mit einem Durchschnittswert zu ersetzen, entweder bei Berechnung von einem durchschnittlichen Zellgehaltswert, oder indem man eine Probe als nicht tolerabel rechnet, wenn man damit meint, dass die Probe eine Zellgehalt über einen bestimmten Wert hat.

Die Resultate 0 und + bei CMT und WsT können möglicherweise mit einem Durchschnittswert ersetzt werden, da die Variationsbreite nicht besonders gross ist und die meisten Proben bei diesen Ausfällen unter $3 \times 10^{5}$ liegen.

Eine Möglichkeit Milchproben zu beurteilen ist, einen indirekten Zellgehaltstest mit einem direkten zu kombinieren, und die niedrigen Ausfälle bei dem indirekten Test zu akzeptieren und die höheren Ausfälle auch mit einem direkten Test zu zählen.

Die indirekten Teste selektieren auf verschiedenen Niveaus. Wieweit man überhaupt einen indirekten Test benutzen kann und gegebenfalls welchen, hängt von dem Selektierungsniveau und der verlangten Sicherheit ab. 


\section{SAMMANFATTNING}

Korrelationen mellan California Mastitis Test, Whiteside Test, Brabant Mastitis Reaction, Catalase Test och direkt cellräkning i mjölk.

Avsikten med undersökningarna har varit att i mjölkprov studera sambandet mellan utfallen vid de indirekta testmetoderna California Mastitis Test (CMT), Whiteside Test (WsT), Brabant Mastitis Reaction (BMR), Catalase Test (CT) och cellhalten, bestämd genom direkt cellräkning (CC) enligt Prescott \& Breed (1910).

Vid undersökningarna har det visat sig att:

Prov med cellhalter inom bestämda cellvärdesgränser inte hänför sig till bestämda utfall vid de indirekta testerna.

Alla fyra indirekta testerna har haft stora variationsbredder för celltalen inom de olika utfallen med stora „överlappningar“ mellan utfallen.

Standard deviationen för celltalen inom de olika utfallen är stor, men en del av denna kan förklaras av att cellvärdena inte är de rätta utan endast skattningar. Korrektion för detta medför emellertid endast en obetydlig minskning.

Korrelationskoefficienten är något högre mellan CMT och CC än mellan övriga indirekta tester och CC.

Om provpopulationer med olika medelcellhalter jämföres är variationsbredder och standard deviationer i stort sett desamma för de olika CMT-utfallen. Medelcelltalen för olika reaktioner ligger emellertid högre, när medelcelltalen på hela materialet är högre, jämfört med ett material med lägre medelcelltal. Detta gäller emellertid inte utfallet 0 .

Medelcelltalen för CMT-utfallen + och ++ har i olika besättningar varierat inom vida gränser.

För alla de fyra indirekta testerna gäller att det inte får anses riktigt att ersätta utfallen med ett genomsnittligt cellvärde antingen det gäller att räkna ut medelcellvärde eller att ange ett prov som icke tolerabelt, om man med icke tolerabelt prov avser att det har en cellhalt över ett visst värde.

Utfallen 0 och + vid CMT och WsT kan möjligen ersättas med ett medelcelltal eftersom variationsbredden inte är så stor och huvuddelen av proven vid dessa utfall ligger under $3 \times 10^{5}$.

En möjlighet till bedömning av mjölkprov är att kombinera indirekt test och direkt cellräkning och godkänna de lägre utfallen vid den indirekta testen och cellräkna de högre.

De indirekta testerna selekterar på olika nivåer. Om man överhuvud taget kan använda någon indirekt test och $\mathrm{i}$ så fall vilken, beror på vilken cellhaltsnivå, man önskar selektera på och vilken säkerhet man fordrar. 